\title{
MANAGEMENT BY VALUES: A CASE STUDY OF A RECRUITMENT COMPANY
}

\author{
Katarzyna Piwowar-Sulej* (D) https://orcid.org/0000-0002-4627-4344 \\ Rafał Mroziewski** (iD https://orcid.org/0000-0003-1551-7128
}

\begin{abstract}
Background. Although one can find in the subject literature how to implement management by values (MBV), this concept is still relatively new and not developed enough. Over the years, it has been proven that there is a direct relationship between management by values and the economic performance of an organization.

Research aims. The aim of the paper is to answer the following research questions: "What are the origin and assumptions of the concept of management by values?" and "How should an organization implement and maintain MBV?".

Methodology. The authors used literature studies and the longitudinal case study method. Within the case study the authors applied participant observations (conducted in 8 years), analysis of documentation and other information about the enterprise under study such as internal reports or website. They interviewed 3 management board members and 8 employees, as well. Then they confronted empirical findings with the "Road Map" concept which is presented in the literature.
\end{abstract}

Key findings. The research revealed some differences between practice and the "Road Map". The study delivers guidelines for managers (e.g., on how to operationalize the company's values, how to build a reward system, or how to measure the success of MBV implementation). The paper also presents the directions for further research.

Keywords: values, management by values, corporate culture, implementation, longitudinal case study.

JEL Codes: M12, M14.

* Departament of Labour, Capital and Innovation, Wrocław University of Economics and Business. E-mail: katarzyna.piwowar-sulej@ue.wroc.pl.

** Departament of Labour, Capital and Innovation, Wrocław University of Economics and Business. E-mail: rafal.mroziewski@gmail.com. 


\section{INTRODUCTION}

Recently, significant changes have been observed in specifying enterprise goals. The absolute primacy of profit is being questioned by introducing new priorities in the form of partial goals, such as customer satisfaction, employee satisfaction, sustainable development, and acting for the benefit of local communities (Lachowski, 2012a).

As Cameron and Quinn pointed out, the sustained market success of many companies is less correlated with market forces than with the values they follow (Cameron \& Quinn, 2003). The system of shared values plays a special role in developing an enterprise's competitive advantage. Organizations classified by Peters and Waterman (2002) - the authors of McKinsey 7S framework - as weaker, either did not provide such a system or the discussed values were not respected there. Weak organizations are also characterized by identifying financial goals as their supreme value. As Mandalaki, Islam and Sobral (2017, p. 11) stated "[if] leaders develop policies intended to achieve mere economistic business objectives with no consideration of cultural values of the organization, change efforts often fail". Managers should be aware that long-term profitability is only achievable if the organization focuses on striving to achieve benefits for different stakeholders of the organization (including employees). This is consistent with the concept of corporate sustainability (Hockerts, 1999).

Value is not a unique concept. Three categories of definitions referring to this term can be listed (Encyclopedia of Management):

1) In the psychological sense, values represent the internal goals of each person.

2) In sociological terms, values stand for the goals of an individual which are generally consistent and accepted by society.

3) Cultural definitions approach value as the desirable goods, judgments, and beliefs which are perceived as a criterion determining an individual's behavior within a group.

In general, value refers to anything that is precious or desirable and constitutes the objective of human endeavor. Value is characterized by cognitive and emotional components (Sagan, 2011). The studies covering the area of philosophy address the problem of the source of values and their variability over time. In turn, according to the definitions presented in management literature, values 
are referred to as both means and goals. Some values are associated with the desired results, whereas others are essential for allowing a particular final state to be achieved. Dolan, Garcia and Auerbach (2003) propose the division of organizational values taking into account basic values (where an organization is heading and why it exists) and operational values (what the ways of thinking and functioning of an organization are and how they achieve basic values). There are many typologies of organizational values. They are based on such criterion for the division as, e.g., the awareness of values, the degree of their codification or "dimensions" (Jaakson, 2010).

Lachowski (2012) highlights that in many companies a catalog, a code, rules of conduct, etc. (the names may vary) remain empty words with little behind them. The probability of market success earned by enterprises is not only determined by the fact they follow specific values, but also by the skill of management by values (MBV). Blanchard and O'Connor (1997) define MBV as a systematic method of identifying and engaging for a common goal and shared values, to be followed by adapting business activities to these values in order to allow all stakeholders to win - shareholders, employees, clients, and other important entities such as suppliers, lenders, or the community. A group of international scholars (Dolan \& Salvador, 2000; Dolan \& Garcia, 2001) states that MBV is a tool to redesign culture in organizations and prepare them for the next millennium. The subject literature presents the assumptions of the concept of management by values. It also provides tips on how to implement and maintain MBV.

Bearing in mind the above, the purpose of the article was defined, i.e., providing answers to the following research questions:

Q1: In the theoretical area: What are the origin and assumptions of the concept of management by values?

Q2: In the empirical and conceptual area: How should an organization implement and maintain MBV?

The subject literature studies addressing the analyzed concept, along with empirical studies based on a single longitudinal case study method were chosen to achieve the purpose of the article. At this point it is worth emphasizing that while searching the English-language literature, covering the problems of interest to the authors of the discussed concept, certain difficulties were encountered. Management by Values (MBV) is also referred to as Value-Based 
Management (VBM). In turn, Value-Based Management (VBM) also stands for enterprise value management. Thus, the issues of psychological values are extended by value expressed in money, i.e., economic value. Search results in the Scopus database indicate that the authors of the majority of articles with VBM as the keyword focus on maximizing shareholder value and such processes as creating, managing, and measuring value (Pietsch, 2006). Relevant literature, methodology, findings, implications for managers, and future directions for researchers are discussed below.

\section{LITERATURE BACKGROUND}

\section{The essence and origins of the concept of management by values}

Management by values has in practice been present, in its pure version, for a long time in non-profit organizations, because - by definition - their sense of operation is a mission which can only be carried out by values. The subject literature addresses the problem of values in sport organizations (Bell-Laroche et al., 2014) and health care (Denier et al., 2019). Research results indicate management by values fully mediates the influence of ethical and social organizational values on organizational performance (Kerwin et al., 2014).

Values and their important role in business were recognized several decades ago. Initially, it was a manifestation of humanization in management. In the $1940 \mathrm{~s}$, when the focus was on enterprise profits, the identified "other" values were slowly becoming the philosophy of operations. Johnson and Watson were the pioneers in this respect as they created a kind of creed for their companies, including such values as quality or respect (Górniak, 2015).

As indicated in the introduction to the study, McKinsey developed the 7S framework. Values were placed in the center of the model due to their key impact on organizational behavior and their essential influence on the direction of operations. They act as a binder for all the remaining six components of an organization. The concept of management by values is derived directly from the aforementioned model. The term was first used by Blanchard and O'Connor and 
published in 1997 in the form of a book entitled Managing By Values: How to Put Your Values Into Action for Extraordinary Results (1997).

In order to analyze the popularity of the MBV idea, Scopus database was utilized. The term "management by values" was used with the constraint to following subject areas: business, economy, and psychology (as well as article title, abstract and keywords). The search area was narrowed down to the publications from 1997, when the aforementioned ground-breaking book was published. The statistics of the obtained publications are presented in Table 1.

Table 1. Statistics of academic publications covering the analyzed subject in the last 23 years

\begin{tabular}{|l|r|r|r|r|r|r|r|r|}
\hline Key word and database & $\mathbf{1 9 9 7}$ & $\mathbf{1 9 9 8}$ & $\mathbf{1 9 9 9}$ & $\mathbf{2 0 0 0}$ & $\mathbf{2 0 0 1}$ & $\mathbf{2 0 0 2}$ & $\mathbf{2 0 0 3}$ & $\mathbf{2 0 0 4}$ \\
\hline Management by Values (Scopus) & 527 & 527 & 657 & 683 & 720 & 793 & 1019 & 1218 \\
\hline & $\mathbf{2 0 0 5}$ & $\mathbf{2 0 0 6}$ & $\mathbf{2 0 0 7}$ & $\mathbf{2 0 0 8}$ & $\mathbf{2 0 0 9}$ & $\mathbf{2 0 1 0}$ & $\mathbf{2 0 1 1}$ & $\mathbf{2 0 1 2}$ \\
\hline Management by Values (Scopus) & 2838 & 3159 & 3395 & 3631 & 3861 & 4583 & 4673 & 4153 \\
\hline & $\mathbf{2 0 1 3}$ & $\mathbf{2 0 1 4}$ & $\mathbf{2 0 1 5}$ & $\mathbf{2 0 1 6}$ & $\mathbf{2 0 1 7}$ & $\mathbf{2 0 1 8}$ & $\mathbf{2 0 1 9}$ & \\
\hline Management by Values (Scopus) & 4365 & 4403 & 4866 & 5517 & 5976 & 6577 & 7698 & \\
\hline
\end{tabular}

Source: authors' compilation.

The analysis of the results from the Scopus database indicates a significant, growing interest in studying the idea of Management by Values. During the analyzed period, as many as 75,839 scientific articles on the problem of the MBV were published. One can notice an almost 15-fold increase in interest in this subject in the analyzed period. Over the last 10 years, the number of publications has increased by $68 \%$, which confirms the continuous growth of research in this area.

Over the years, it has been proven that there is a direct relationship between management by values and the economic performance of an organization. For example, the National Tooling \& Machine Association's research shows that enterprises focused on improving quality by adapting their operations to core values, i.e., reliability, responsibility, and honesty, achieve greater profits than the ones focused on quality alone (Stachowicz-Stanusch, 2007). Therefore, it is not surprising that values are sometimes referred to as profitability generators, because it is owing to them that an enterprise achieves better financial results. 
Shared values boost an organization's performance in a number of ways (Titov \& Umarova, 2017):

- as a result of shared values, employees make better decisions,

- management knows what kind of behavior and work to expect,

- they create unity in a team, leading to consistent behavior,

- knowing and believing in values increases the probability of making the right decisions that support those values,

- congruence of values improves work engagement.

In other studies, carried out by Collins and Porras (2004), the analysis covered 18 companies that had consistently been successful in achieving exceptional market results for over 50 years. The objective was to identify common features characterizing such visionary enterprises. The authors concluded that one of the elements distinguishing these organizations from their competition were values which actually affect every decision made. Management by values does not replace traditional management approaches, but rather develops and complements them. It does not work in organizations where leaders do not believe in trust, but rather want to control it. It is a system that helps a company really make the leap from being good to being perfect (Ibarreche, 2016).

According to Chelladurai and Kerwin (2017), management by values is also an increasingly common practice in non-profit sport organizations, resulting in a very positive impact. The authors cite two interesting survey studies; in one of them, held in Canadian sport organizations, it was found that strategically adopting MBV in practice, fully mediated the influence of organizational values on organizational performance. In the following case study it was found, that for corporate values to be understood and executed by employees, values must be rooted in everyday policy and practice of HR management. Moreover, values should be strategically managed to enhance organizational performance

Jaakson (2009) analyzed the results of 12 research projects carried out in the years 2000-2008 regarding the relationship between values and results (individual and organizational). In most cases this relationship was confirmed.

Three types of values can be distinguished within the framework of organizational culture, namely (Dolan et al., 2006; Jaakson, 2010):

- economic/survival - covering efficiency standards, 
- ethical and social - including humanity values and behavioral patterns at work,

- emotional, developmental and well-being values - related to internal employee motivation.

Economic values are essential for the company's survival. The ultimate goal of a company's existence is to create value, in particular financial value. If an organization fails to create it, it simply disappears. However, with regard to economic values, people working in the organization are not just a part of the mechanism. This means that not only their skills, but also their emotions are important.

People and their personal characteristics are the essence of MBV. Theirs identity, values, beliefs, courage, ethics, creativity and self-esteem play a crucial role here. They will always remain the most important assets of the organization. Even though machines are replacing man, it is always man who creates them (Harung \& Dahl, 1995). Therefore, the compatibility between individual and organizational values or between the values of work and life is important for a sustainable and healthy organization (Zhang et al., 2009). The coherence between the values held by the company and the individual values of its employees leads to optimal use of human resources (Zavyalova, 2009). When individual goals and values become aligned with corporate goals and values, this configuration accelerates the use of the organization by individuals and their readiness to engage in social interactions within the company, positively influencing its functioning, e.g., through better use of knowledge (Delshab et al., 2019).

Since the 1990s, the importance of controlling economic and pragmatic values has been in decline, whereas the importance of ethical values has increased significantly. In addition, a greater emphasis on development and emotional values has been observed among specialists, and primarily in the growing services sector (Encyclopedia of Management).

How does defining values and later adapting enterprise activities to these values enhance success in business? First of all, there is probably no manager who disagrees with the statement that employees constitute the foundation of the company. It is the people who decide about the success of an enterprise, regardless of whether it is a start-up or an international corporation. Because of values, employees feel united, get more involved and, as a result, their potential, passions, and talents can be taken advantage of to the fullest. 
As pointed out by Lachowski (2012), ordinary people can become exceptional, they are capable of working miracles if guided by several basic values. A well-coordinated team following shared values as its basis is more effective and, as a result, achieves better outcomes, thus ensuring its organization a competitive advantage.

In the same vein, Swaroopa and Chandrasekhar (2019) state that teamwork is a critical foundation for every organization. They conclude that team members could be great performers individually, but if the appropriate values are missing, they would fail to be effective as a team and would not manage to bring their best out. However, if certain values such as flexibility, empathy, respect for others or patience are present, they will be able to achieve great results, even if they are not great performers individually.

Values, which constitue a part of enterprise organizational culture, remain an essential component of the process aimed at implementing the mission and strategy of an enterprise. They play an important role in introducing changes. For example, a culture in which knowledge is a value, along with the free flow of information resulting in its creation, facilitates better effectiveness of an organization. Common values meet employees' security and affiliation needs. Owing to shared values, employees can refer to a common basis for assessing individual behaviors, decisions, attitudes, and motivations. There is no doubt about what is right and what is wrong (Lipinska, 2010; Chandrakumara, 2011).

Undeniably, effectively functioning rules are also an important factor for employers, resulting in the candidates' perceptions of a company as unique. It is of major importance in the current labor market, dominated by employees who - while searching for the right workplace - are more inclined to choose the one which allows them to live fully in accordance with the observed rules. This factor is gaining significance and may prove more important than financial incentives, thus constituting a strategic competitive advantage for the company. Employees following common rules simply like working together, so their motivation increases, which, in turn, results in greater success at work. Therefore, values can help attract people (i.e., future employees and team members) whose values are congruent with the organization (Bell-Laroche et al., 2014).

The impact of skilful management by values on reducing staff turnover is also significant (Sobiecki, 2015). Recruitment outlines internal values, with the aim of attracting, developing and maintaining 
a segment of the available workforce that is able to identify itself with these values. An employer may be able to attract virtually anyone who comes to work for the organization if they are offered enough money. However, retaining an employee will require more than money. The employee will remain when he or she perceives that operational standards not only enhance and protect the organization's values, but also the employee's personal values (Goll, 1990). Individual values that are congruent with an organization's values may strengthen an employee's identification with the organization and ultimately provide employees' meaning, direction and a sense of what is distinctive about the organization (Paarlberg \& Perry, 2007).

The researchers from Cracow University of Economics carried out studies in 2015 to learn about the determinants of employee organizational involvement in taking actions, where the role of values was considered the point of reference. The analysis of their findings showed that the values most frequently indicated by all respondents were responsibility and companionship. Next on the list were: appreciating commitment, trust, and cooperation, respectively. The results of these studies differed depending on the respondents' gender. Women more often pointed to such values as honesty, selfless help, and allowing mistakes. In turn, men predominantly indicated creativity, which suggests a more task-oriented attitude focused on effectiveness. Therefore, different expectations of both genders should be taken into account in the process of constructing involvement in an enterprise (Górniak, 2016).

Above, much space has been devoted to the impact of values on employee behavior. At this point it is worth paying attention to other stakeholders of enterprises, as mentioned in the introduction to the article. As a result of management by values ideas such as sustainable development can be implemented (Herman \& Konopka, 2013).

As it has already been emphasized many times, the values functioning in practice, rather than in declarations only, determine whether the desired effect is achieved. Therefore, the process of introducing the concept of management by values followed by maintaining consistency of operations is of great importance. The larger the organization, the longer the MBV implementation takes, but a total of about three years can be assumed. If the actual management by values is to function properly it has to be implemented on an ongoing basis, without any interruptions and in all areas by the entire organization team (Blanchard \& O'Connor, 1997). 


\section{The "Road Map" of management by values}

It is no great feat to proclaim rules; success comes with their consistent implementation and application in every business situation. Only observing rules on a daily basis can result in measurable effects. The guidelines on how to do it are presented in both scientific and business literature.

To achieve the expected results, as Światek-Barylska (2010) rightly notes, employees have to be aware of the values and accept them (identify with them), whereas the management techniques applied in the company have to support the declared values. Obviously, an example to follow comes from the top, therefore, strict compliance with the set standards by the owners, management board, and managerial staff remains a prerequisite for success.

Blanchard and O'Connor (1997) distinguished three phases of MBV implementation, namely:

1. Specifying the mission or purpose and values.

2. Communicating the mission and values.

3. Aligning daily practices with the mission and values.

In the first phase, it is crucial to get approval from the company management or owners to initiate the process. Next, it has to be decided what values the adopted business strategy is going to be based on. The company mission should reflect its key values. Subsequently, the involvement of managers is extremely important because values cannot be imposed on anyone; they should be developed jointly. After consulting the management team and developing a common list of values and the mission, it has to be discussed with employees to find out what their opinions are. This will help in estimating whether employees will get involved in the implementation of the mission and comply with the rules.

It should be remembered that determining the values is crucial both for the present and future of the company. As Lachowski (2012) notes, there is no rule that says that a company without defined values cannot achieve success. However, it can be stated that the probability of companies achieving success increases significantly by not only formulating such values but also by implementing them in business operations. Values may seem abstract to employees. Naming and defining them can help everyone understand what is important in the workplace. For this purpose, the Minessence 
1

Specifying the mission
or purpose and values
- Obtaining approval from
the board or co-owners
- Decision on values
- Consultations with managers
- Developing a common list of
values
- Discussing values with
employees

$-2$

Communicating the mission

and values

- Initial meetings in each location

- Acquiring at least basic knowledge of the rules by employees

- Visual enhancement of values

- Developing a decision-making guidebook

- Communicating rules to other stakeholders

\section{3}

Aligning daily practices with the mission and values

- Aligning daily practices with the mission and values

- Providing feedback to management whether the rules work

- Taking corrective actions

- Taking into account employees' ideas and suggestions

- Values become the way of resolving conflicts

- A collection of success stories as examples of how rules work

- Values are manifested in all areas of activity, i.e.:

$\begin{array}{ll}\text { a) Recruitment } & \text { f) Remuneration }\end{array}$

b) On-boarding g) Motivation

$\begin{array}{ll}\text { c) Training h) Customer } & \end{array}$

d) Employee relations

assessments i) Financial

e) Promotions results

Figure 1. Management by Values - "Road Map"

Source: authors' compilation based on Lachowski, 2012, pp. 273-287.

Values Framework, which consists of 128 discrete and universal values and descriptions, can be used for example (Value Descriptors, 2019). It is vital that employees understand core values precisely, accept them and as a consequence make appropriate decisions or take up actions, that are consistent with values. Employees, being a link between the company and the environment, through their behavior and declaration what is the most important for their firm, determine how the organization will be perceived by partners, potential clients, and society (Marek, 2018).

It is best to start communicating the developed values and the mission during initial meetings in each location of the organization. All employees should have at least a basic awareness of them. To strengthen the signal, posters can be hung around the entire company, pictures to put on desks can be prepared, placed at the entrances to buildings, in conference rooms, on business cards, or in company publications. The space on all marketing materials, gadgets, or gifts can be used for this purpose, but also as one of the leading topics during internal meetings in the company. Another interesting idea is a value-based decision-making guide. Graphic 
elements representing particular values will strengthen the message, especially for visual learners. It is also recommended to communicate the Code of Conduct outside the company to develop good relationships with all stakeholders.

The third phase was described as the heart and soul of the whole process of implementing management by values. Feedback to the management, which verifies whether the values work in practice, is required here. It offers opportunities to take corrective actions. Next, employees should be asked to share their ideas and suggestions. Common values should become the way for resolving conflicts among employees. Over time, it is worth collecting success stories to serve as a vivid example of how rules work in practice.

Based on the experience of mBank, Lachowski (2012) developed the so-called "MBV Road Map" (see: Figure 1).

Even from the moment of implementing management by values, the essential element is to recruit such employees to an organization whose standards and goals coincide with those functioning in the company. At the same time, rules can be used as an attractor for talented candidates following similar values in their lives. They definitely represent an underrated recruitment tool. Attracting and choosing the right people as well as developing them will play an important role in the further development of the company.

Recruiting appropriate employees should start with the consistent development of employer branding, based on the chosen values. Values should act as guidelines in the company's communication with the labor market. The more concisely and clearly the company values are presented, the more adequate candidates apply for a job in the organization. In this way, the costs of hiring and future staff turnover are simultaneously reduced.

A competency profile can be used in the process of employee recruitment, which defines clearly what characteristics and attitudes are sought for among the candidates for the job. In practice, they often turn out to be more important than education, skills or experience. It is also worth using a behavioral interview, which not only shows how the candidate behaves in specific situations but also offers an opportunity to assess whether such a behavior is desirable for the company.

After finalizing employment, the on-boarding process cannot be forgotten as it introduces an employee to the actual reality of 
the company and plays an important role in stabilizing employment. It is often the key period, which has an impact on further success. After joining a company, a new team member begins to function among other people in a defined organizational culture. Since an employee is an adult with an already established personality, knowledge, and system of values, the manager can influence his or her behavior not by changing the person, but by appropriately shaping the work environment. As flexibility is the number one organizational principle nowadays, managers have to create a work environment making decisions on the continuum between formalization and management by values. Successful implementation of MBV results in a higher level of employees' commitment, job satisfaction, and a diminished turnover intention rate (Świątek-Barylska, 2017).

Subsequently, the rules should also be included in the following activities of an organization (Lachowski, 2012):

- assessment of attitudes and skills;

- staff training;

- rewards for achieving results (bonus system);

- programs for managers aimed at raising their awareness of the power of management by values. They should be capable of defining employees' expectations which are consistent with the values, assessing them in terms of both results and attitudes and managing employees by developing the competencies which are essential to preserving values;

- promotions and succession programs, talent management;

- cooperation with suppliers.

Holding onto value in the long run, as a business compass, is certainly not easy and requires consistency. In practice, after implementing MBV, it is important not only to assess how values are incorporated in different procedures, but also to assess how values are used and understood (Kerwin et al., 2014). Determined and strong leadership is essential to function as the role model. In order to check whether leadership by values is effective not only at the strategic but also at the operational level, a diagnosis should be carried out to determine the compatibility between the two levels. The focus should be placed on the indicators combining work and values. The following elements can be checked: the level of identification with the organization, the existence of an informal structure supporting communication, dignity-based satisfaction and the type 
of motivation system or emotional relationship with the products or services (Ambroziak, 2012). Taking part in the Great Places to Work "Trust Index" study, which evaluates employees' opinions about their own behavior, in the context of organizational values, is also an option (Hancock, n.d.). In the case of discrepancies, it is recommended to undertake actions aimed at eliminating them.

\section{RESEARCH METHODOLOGY}

\section{Description of the case study method}

The case study method was applied in the present research. Yin (2013) recommends this method in order to find responses to questions of an exploratory nature, i.e., the ones referring to "how" and "why" a given phenomenon occurs. Such research is focused, to a greater extent on an in-depth understanding of a given phenomenon, rather than on the analysis of variables. As it was indicated above, the objective of the empirical part of the article is to answer the following question: How should an organization implement and maintain MBV?

The choice of a single longitudinal case study method is justified by the period of the studied phenomenon (in the analyzed case the research covers over eight years of an enterprise's operations). A single case study is also desirable when the theory covering the selected problem refers to a particular context (Walsham, 1995). The MBV-related practices presented in the subject literature have a specific organizational context. For example, the "Road Map" by Lachowski (2012) was developed based on the author's experience in managing banking institutions. To answer the second research question, the information collected in the case study was confronted with the concept of the "Road Map".

The case study is illustrative in nature as it represents - according to the categorization presented in the subject literature (Stake, 2005; Yin, 2013) - instrumental and primarily retrospective cases. Instrumentality is manifested in analyzing a particular case study in its actual context, whereas the reference to both the past and present of an organization's functioning means retrospection.

The authors applied participant observations, analysis of documentation and other information about the enterprise under study 
such as internal reports or website. Three management board members and 8 employees were interviewed as well.

\section{Characteristics of the company under study}

The Mondi brand was established in Germany in 2002, when Baumann founded Mondi $\mathrm{GmbH}$ in two locations simultaneously, i.e., in Esslingen and Offenburg. In 2010 the parent company established Mondi Polska Agencja Pracy Sp. z o.o. (Mondi Polska in short). It specializes in the recruitment of temporary employees to German-speaking markets. Currently, more than thirty specialists are internally employed in Mondi Polska, who provide recruitment services for external clients and subsidiaries, i.e., Mondi Pro, Pagus, and Mondi Personal. At present over 300 specialists from various industries are working on projects carried out by the organization and its related companies.

The parent company follows its own rules specified by the owners and referred to as the "vision" or the "7 rules", namely:

1. The ideas of each of us open new perspectives for the future.

2. People are always at the center of our actions.

3. Mutual support and development expand our competences.

4. The achievements of all employees contribute to success.

5. The experience gained is the basis of our activities.

6. We develop solutions tailored to our clients' needs.

7. The highest quality remains our goal.

These values were not imposed by the German company on its subsidiaries. The Mondi Polska team operates completely independently and all decisions are made at the national level. This also applies to the implementation of the concept of MBV.

\section{FINDINGS}

\section{Stages of the MBV concept implementation in the company under study}

At the stage of establishing the analyzed company, the managers already had a clear idea regarding the desired characteristics of the organizational culture. In the first days of operation the company 
mission was formulated: "We fulfil the dreams of an ideal partnership between people and companies".

"Partnership" is the key word in the company mission, referring to the preferred type of relationship. Mondi Polska works a bit like a matchmaker who is guided by hard data, but also the sixth sense of intuition, connecting people and companies into pairs. It wants the candidates to find the perfect bosses and the business owners to find their dream employees. This mission guides every employee of the company towards appropriate actions and helps in making difficult decisions. When the cooperation lacks the key partnership for Mondi Polska, the company resigns from further relations, even if it means withdrawing from a lucrative contract. It is not always easy, but it helps the company to function fully in line with its beliefs.

Due to the fact that relationships are so important to Mondi Polska, the HR concept was redefined. For the company it does not mean Human Resources but Human Relations. The company believes in people rather than resources. The answer to the question which client is the most important is: every client. It opposes the objectification with care, misunderstanding with sensitivity, mediation with support and uses an individual approach instead of a mass scale. Elsewhere, the attitude of indifference is frequently followed, whereas in Mondi Polska there is empathy. Where only numbers counts in the area of Human Resources, in the case of Mondi Polska the term "Human Relations" ensures partnership.

From the very start, the enterprise managers assumed that employees should enjoy the time they spend at work. Therefore, in the first months of operation, more than eight years ago, the company engaged the then entire team in a brainstorming session. The goal was to identify the most important standards and values followed by the employees in their lives. Ultimately, 10 most important values were selected (see: Table 1).

In order to communicate the rules properly to all current and future employees, as well as business partners and all other stakeholders, a number of actions were undertaken. First of all, the values were thoroughly described and supported by specific examples from everyday life in order to illustrate and understand them better (see: Table 1). 
Table 2. Operationalization of Mondi Polska enterprise value

\begin{tabular}{|c|c|c|}
\hline Value & Development & Example \\
\hline Respect & $\begin{array}{l}\text { We treat others as we } \\
\text { would like to be treated. } \\
\text { Regardless of how difficult } \\
\text { the tasks we face are and } \\
\text { how difficult the emotions } \\
\text { associated with them are, } \\
\text { we can be sure of maintain- } \\
\text { ing high culture of commu- } \\
\text { nication. In MONDI, we } \\
\text { respect each other. }\end{array}$ & $\begin{array}{l}\text { Let's assume that you have recruited an } \\
\text { employee whose CV suggested that he/ } \\
\text { she has extensive experience in his/her } \\
\text { field. However, the coordinator rejects his/ } \\
\text { her candidacy, deciding that he/she will } \\
\text { not cope with the proposed position. It is } \\
\text { natural that you do not understand such } \\
\text { a decision - maybe you get angry and } \\
\text { think badly about the coordinator. You feel } \\
\text { negative emotions. The best solution is } \\
\text { to ask for a conversation and explain this } \\
\text { situation in a polite way. }\end{array}$ \\
\hline Common goals & $\begin{array}{l}\text { Each of us is different } \\
\text { and has different respon- } \\
\text { sibilities, but we strive } \\
\text { for achieving a common } \\
\text { goal. We take care of it } \\
\text { at the very beginning, } \\
\text { when a new person joins } \\
\text { the team. We remember } \\
\text { about clear and continuous } \\
\text { cooperation. } \\
\text { It is not always easy, but we } \\
\text { try because cooperation is } \\
\text { the key to achieving a com- } \\
\text { mon goal. }\end{array}$ & $\begin{array}{l}\text { One of our common goals is to carry out } \\
\text { orders so that customer service is of } \\
\text { the highest quality. } \\
\text { Each of the Recruitment Specialists has } \\
\text { their individual tasks: recruitment of can- } \\
\text { didates, recruitment interviews, arranging } \\
\text { manual tests, making appointments for } \\
\text { preliminary examinations, preparing con- } \\
\text { tracts and completing formalities related } \\
\text { to the employment of an employee. } \\
\text { All these tasks lead to our common goal, } \\
\text { which is customer satisfaction. Each of } \\
\text { us is focused on our own individual tasks, } \\
\text { but is also aware of our priorities, that } \\
\text { the quality of services provided has to be } \\
\text { at a high level, that we have to anticipate } \\
\text { many issues, cooperate efficiently and con- } \\
\text { tinuously, so that the flow of information } \\
\text { runs smoothly. }\end{array}$ \\
\hline Team success & $\begin{array}{l}\text { Success tastes great, and } \\
\text { even better if we have some- } \\
\text { one to share and celebrate } \\
\text { it with. In MONDI, we help } \\
\text { each other and cooperate. } \\
\text { After all, we play for one } \\
\text { goal. }\end{array}$ & $\begin{array}{l}\text { In the summer of } 2015 \text {, we implemented } \\
\text { a large project. One day } 25 \text { people were } \\
\text { to start working for our client in Germa- } \\
\text { ny. Cooperation between recruiters and } \\
\text { coordinators was crucial in this matter. } \\
\text { We had to take care of many aspects, such } \\
\text { as: signing contracts, arranging accom- } \\
\text { modation, transport, dividing employees } \\
\text { into departments, etc. We could rely on } \\
\text { each other, it was a joint effort. Later, we } \\
\text { enjoyed the success and were proud that } \\
\text { together we managed to carry out such } \\
\text { a difficult task. }\end{array}$ \\
\hline Loyalty & $\begin{array}{l}\text { In MONDI, we are a team } \\
\text { whose foundation is work } \\
\text { based on mutual trust. } \\
\text { We believe that loyalty is } \\
\text { the key to success. Although } \\
\text { everyone is different, we go } \\
\text { in the same direction and } \\
\text { believe that we can rely on } \\
\text { each other. Each obstacle is } \\
\text { a challenge for us. }\end{array}$ & $\begin{array}{l}\text { I was worried about what would happen if } \\
\text { I go on holiday - what about the employees } \\
\text { I usually look after. Not necessary! Here } \\
\text { in MONDI everything is organized. When } \\
\text { I go on holiday, I can always rest assured } \\
\text { that each of my colleagues, who will take } \\
\text { over my duties, will ensure work continui- } \\
\text { ty. It never happened that after returning } \\
\text { from holidays a pile of documents and } \\
\text { unfinished issues was waiting for me. }\end{array}$ \\
\hline
\end{tabular}




\begin{tabular}{|c|c|c|}
\hline Value & Development & Example \\
\hline $\begin{array}{l}\text { Efficient } \\
\text { communication }\end{array}$ & $\begin{array}{l}\text { One can speak and not be } \\
\text { understood, one can listen } \\
\text { but not hear. That is why } \\
\text { in MONDI we constantly } \\
\text { talk with each other, which } \\
\text { is why we understand each } \\
\text { other better. As a result, } \\
\text { we always achieve a joint } \\
\text { success. }\end{array}$ & $\begin{array}{l}\text { We exchange information on an ongoing } \\
\text { basis, i.e. who runs which project and what } \\
\text { is the stage of its progress. For example, } \\
\text { having information that a colleague is look- } \\
\text { ing for a salesman to work in the Mazovia } \\
\text { Province, I know that I can refer to her all } \\
\text { candidates from this region who have also } \\
\text { applied for my recruitment. We commu- } \\
\text { nicate problems rather than keep them } \\
\text { to ourselves. By talking about them we can } \\
\text { also help each other. }\end{array}$ \\
\hline Responsibility & $\begin{array}{l}\text { We are responsible because } \\
\text { we constitute one link } \\
\text { in the chain of which people } \\
\text { are the beginning and } \\
\text { the end. We are responsi- } \\
\text { ble and, therefore, clients } \\
\text { order recruitment from us } \\
\text { because they know we will } \\
\text { do our job professionally. } \\
\text { Employees, in turn, trust } \\
\text { that we will take care of } \\
\text { them. }\end{array}$ & $\begin{array}{l}\text { It happened that a new colleague added too } \\
\text { much allowances to employees' salaries. } \\
\text { The mistake was detected in time, but we } \\
\text { joked that the employees would surely } \\
\text { be happy with it; however, if it goes on } \\
\text { like this, the colleague will have to cover } \\
\text { the excess from her own salary. Mistakes } \\
\text { happen, but it should be remembered that } \\
\text { both the work and remuneration of many } \\
\text { people depends on our actions. }\end{array}$ \\
\hline $\begin{array}{l}\text { Drawing } \\
\text { conclusions }\end{array}$ & $\begin{array}{l}\text { All people make mistakes, } \\
\text { so do we. We are not afraid } \\
\text { of them; on the contrary - } \\
\text { we try to draw conclusions } \\
\text { from every single mistake } \\
\text { so as to avoid replicating } \\
\text { them. Owing to mistakes } \\
\text { we have an opportunity for } \\
\text { self-improvement. }\end{array}$ & $\begin{array}{l}\text { At the beginning of my work in MONDI } \\
\text { I booked accommodation for employees } \\
\text { in a hotel in Germany. On Friday afternoon } \\
\text { I said goodbye to the work week and wel- } \\
\text { come the weekend. I did not take the busi- } \\
\text { ness phone from the office because I was } \\
\text { still a new employee and such employees } \\
\text { were looked after by a more experienced } \\
\text { colleague. I was taken by surprise on } \\
\text { Monday morning when I found out that } \\
\text { the employees were spending the night } \\
\text { in their car. } \\
\text { What is the conclusion? Confirmation } \\
\text { of the accommodation booking is not } \\
\text { everything. A booking guarantee is } \\
\text { also needed. This situation taught me } \\
\text { a lesson that one has to remember about } \\
\text { everything. I drew conclusions from this ex- } \\
\text { perience and a similar situation has never } \\
\text { happened again. }\end{array}$ \\
\hline $\begin{array}{l}\text { Constructive } \\
\text { solutions }\end{array}$ & $\begin{array}{l}\text { It is extremely important } \\
\text { for us to develop the ability } \\
\text { of using constructive solu- } \\
\text { tions in everyday work and } \\
\text { common communication. } \\
\text { Creating new, better ways } \\
\text { of cooperation and alterna- } \\
\text { tive methods of operation } \\
\text { allows us to meet the needs } \\
\text { of our clients, candidates } \\
\text { and ourselves. }\end{array}$ & $\begin{array}{l}\text { It is important that we talk to each other, } \\
\text { i.e., if any of us has any problems with a re- } \\
\text { cruitment, we hold a brainstorming session } \\
\text { in order to work out common solutions. } \\
\text { We exchange views and experiences, take } \\
\text { up a discussion and search for answers } \\
\text { to questions. }\end{array}$ \\
\hline
\end{tabular}




\begin{tabular}{|c|c|c|}
\hline Value & Development & Example \\
\hline Truth & $\begin{array}{l}\text { We are honest and truthful } \\
\text { with ourselves and also } \\
\text { with the candidates and } \\
\text { clients. We cannot imagine } \\
\text { it otherwise. In MONDI } \\
\text { all relationships are based } \\
\text { on honesty and trust. } \\
\text { After all, you cannot trust } \\
\text { someone who is not honest } \\
\text { with you. Cooperation will } \\
\text { not develop well if you do } \\
\text { not comply with this rule } \\
\text { because you want to present } \\
\text { yourself in a more favorable } \\
\text { light than it would appear } \\
\text { in a given situation. We } \\
\text { consider such behavior } \\
\text { immature and harmful } \\
\text { to others. }\end{array}$ & $\begin{array}{l}\text { At the beginning of my work it turned out } \\
\text { that I had paid the same bill twice. I was } \\
\text { very afraid to admit my mistake because } \\
\text { I was concerned that the rest of the team } \\
\text { would consider me an incompetent person. } \\
\text { Nothing could be further from the truth. } \\
\text { It is only those who do nothing that make } \\
\text { no mistakes. Obviously, I reported what } \\
\text { happened and it was good that I did so. } \\
\text { Thanks to the quick reaction of the girls } \\
\text { from the department, we managed to get } \\
\text { back the money I had overpaid by mistake. } \\
\text { However, I found out that it is worth being } \\
\text { honest, because that is the only way one } \\
\text { can get help in time and come up with } \\
\text { the right solution. }\end{array}$ \\
\hline Our company & $\begin{array}{l}\text { The development of } \\
\text { the MONDI brand in Po- } \\
\text { land was initiated by people } \\
\text { who, from the very begin- } \\
\text { ning, had a clear vision and } \\
\text { strategy of action based on } \\
\text { strong values. They were, } \\
\text { and still are, full of endless } \\
\text { optimism and faith that } \\
\text { everything will work out } \\
\text { well if it is truly believed } \\
\text { in. After a few years of hard } \\
\text { work and building a com- } \\
\text { pany brick by brick, like } \\
\text { our own, now we can enjoy } \\
\text { it together and be proud of } \\
\text { who we are and what we } \\
\text { are like. }\end{array}$ & \\
\hline
\end{tabular}

Source: author's compilation based on Mondi's internal materials.

As Aristotle once said, "everything starts with the eye"; thus, when attempting to reinforce the message of the company's code of conduct, graphical elements were developed to symbolize individual values. Posters presenting all the rules were prepared and placed in such crucial places as the reception desk or conference rooms. At the same time, the concept of hanging one poster presenting a given value in each room was suggested. In this way, by moving around individual offices, one can gradually learn about the company values. Next, due actions were taken up in the area of human resources management, which are being implemented to this day and, therefore, will be presented in the following part of the case study. 


\section{Actions taken as part of management by values}

The management board of Mondi Polska is convinced thet all competencies can be learned over time, and that the company is, therefore, capable of educating an employee properly. However, it is difficult to change the values accepted by a particular person. For this reason, as the CEO of the company states, "they are the main factor taken into account by company when selecting candidates, during their development process and also when making decisions about contract termination". The company knows, based on its experience, that the rules candidates learn about even before the interview are a critical factor for them when choosing a future employer.

At the end of the seven-stage process focused on selecting candidates for work, the entire team participating in this process discusses the candidate's profile based on the information collected using not only methods such as an interview, but also based on the trial day and the Insights Discovery test.

After hiring an employee, his/her orientation in the company begins, which is often a key factor determining long-term success. On the first day of work an employee first meets the President of the Management Board. The on-boarding period starts with presenting the history of the company, its shareholders, as well as the structure of the entire group, including the description of specializations of the individual subsidiaries. However, the most important element is to clarify the company's mission and its functioning rules. Each of the values is thoroughly analyzed and supported by substantive examples from life. The employee is told that he/she was employed on the basis of these rules. It is those rules, or rather following them, that will also be decisive in his/ her development and promotion; however, if they are not respected they will become the main reason for his/her dismissal. The idea of Human Relations is also specified, as well as the successful areas and awards achieved by the company.

The company prepared Mondi Employee Handbook, which describes in detail the way the company operates, with a particular emphasis on its mission and the applicable rules. At the subsequent stages of implementation and later in the course of everyday work, the company milestones remain the basic indicator of proper conduct. 
The management board of Mondi Polska believes that the appropriate motivation of an employee and the recognition of his/her exceptional contribution is one of the key elements of the company's success. It has been highlighted in many studies (e.g., Mikkelsen et al., 2017; Cho \& Perry, 2012) that individual praise is more valuable than group recognition, and that apart from being appreciated by our superiors, we also care about the respect of our colleagues, including those working in other departments.

Appreciation of employees is one of their main motivators. Therefore, the company has developed a solution which supports this need and, at the same time, as Managing Director of Mondi Polska assesses, "strengthens the essence of the existing values". All of these components were included in the internal incentive system called the Proper Recognition Of Professional Skills - P.R.O.P.S.

Employees and their superiors may be praised in the following forms:

- Mini-Props. They have a value of 2 points when awarded in a given department and 4 points when awarded outside it.

- Mega-Props. They have a value of 2 points when awarded in a given department and 4 points when awarded outside it.

Mini-Props can be awarded for all the activities bringing the company closer to achieving a strategic goal, compliance with the rules and also for such desirable behaviors as, e.g., support, respect, reliability, kindness, responsibility, putting the team's success above an individual's, passion, honesty, exceptional communication, ingenuity, inspiration, punctuality, problem-solving, special commitment, help, innovation, perfect feedback, social involvement, mood-improving, or taking an initiative.

Mega-Props are awarded for exceptional achievements, in particular ones which significantly contribute towards achieving the company goals and also for a unique pro-team attitude.

The system has been enhanced by a bonus factor. After collecting 100 points, they are converted into actual employee points to be used in the MyBenefit cafeteria system. In the opinion of the management board, such a solution has many advantages in the context of management by values as it:

- allows immediate recognition of an employee by his/her superiors as well as by colleagues and subordinates;

- results in a significant increase in motivation; 
- supports specific behavior that is highly valued by the company;

- contains elements of gamification;

- positively affects employees' retention in the company and reduces staff turnover;

- supports cooperation between teams by properly assigning weight to points in the department and outside it;

- increases employee productivity;

- offers an attractive opportunity to convert points;

- supports decision-making regarding promotions - people who have earned the highest number of earned Props are naturally predisposed for that.

HR Manager points out that focusing on employee development, the company organizes training which pays special attention to tailoring their program to the needs of Mondi Polska and considers the standards prevailing in the organization. Each time the trainers are informed about the rules followed in the company and are also asked to take them into account in the training presentations.

The rules often represent a leitmotif of company events. Most frequently, the idea of a trip is based on solving physical and logical tasks, for which groups obtain, e.g., parts of a code or a password. At the end, the involvement of the entire team is decisive in the overall success, because only by collecting and combining all the elements of the password can the team come to a common solution, i.e., the names of the rules or, as in a recent case, the Human Relations slogans.

As the Marketing Specialist at Mondi stated: "the monthly internal newsletter is yet another manifestation of how the rules work in Mondi Polska". To emphasize its role, it was named Good Relationships. It presents the milestone anniversaries of individual employees, reports from company events or training sessions and marketing activities.

The representatives of Mondi Polska do not forget about the rules in their contact with clients, either. The approach to cooperation is always a long-term one. As a rule the Team's success is approached with a wider perspective, which means that the organization strives to enter into relations with the clients with whom it is possible to achieve common success, so thet all parties involved in the cooperation are satisfied in the long run. Effective communication often remains one of the important factors determining positive results. Mondi's Head of Administration, acknowledged: "The crucial aspect, especially in the cooperation with a demanding German client, is 
learning from mistakes". Contractors aim at the continuous quality improvement of the services provided by Mondi Polska; therefore regular meetings are organized, during which clients identify the potential areas for improvement. The company, by implementing them as agreed, guarantees a long-term partnership.

In order to verify the knowledge and functioning of the rules in practice, Mondi Polska conducts quarterly, anonymous employee satisfaction surveys. Some of the questions contain points about the functioning of the company values. In the last survey conducted in March 2020, the following weighted averages were obtained from respondents' assessments:

- to the question: "To what extent do you understand the values we follow on a daily basis?" - result 9.8/10

- to the question: "To what extent do you think the Mondi's values work in practice?" - result 8.8/10

- to the question, "Does your supervisor follow Mondi's rules?" result $9.2 / 10$

- to the question: "Are your personal values consistent with Mondi's?" - result 9.7/10

The recently conducted research clearly shows that the degree of understanding of the company rules and their consistency with individuals' principles remains at a very high level of $97 \%$. Compliance with standards in practice is assessed at an exemplary level of $88 \%$ and - worth highlighting - the superiors follow the rules.

\section{Discussion}

As indicated above, the subject literature attracts attention to the need to define economic (efficiency standards), social/ethical and emotional/ developmental values. Simultaneously, in the service sector attention is paid primarily to the last two types of values. In the business under study - which is a service company - the focus is on social/ethical and emotional/developmental values. The organizational culture of this company does not perceive efficiency standards as values. It is owing to social/ethical and emotional/development values that the efficiency standards are achieved.

"Strong" values, i.e., the ones which, according to the research results presented in the first part of the article, guarantee the enterprise success, are as follows: reliability, responsibility, honesty, 
companionship, appreciating commitment, trust, and cooperation. In Mondi Polska, the list of 10 values includes responsibility, honesty (truth), and cooperation (common goal).

Table 3 compares the literature guidelines for implementing the MBV concept with Mondi Polska's practice.

Table 3. The comparison of Mondi Polska's practice with the literature guidelines for implementing MBV

\begin{tabular}{|c|c|}
\hline Literature guidelines & $\begin{array}{l}\text { Method of MBV implementation } \\
\text { in Mondi Polska }\end{array}$ \\
\hline $\begin{array}{l}\text { 1. Specifying the mission or purpose and values } \\
\text { 1.1. Obtaining approval from the board or } \\
\text { co-owners } \\
\text { 1.2. Decision on values } \\
\text { 1.3. Consultations with managers } \\
\text { 1.4. Developing a common list of values } \\
\text { 1.5. Discussing values with employees }\end{array}$ & $\begin{array}{l}\text { Generally in accordance with the litera- } \\
\text { ture guidelines } \\
\text { Differences: } \\
\text { - The board's approval was not necessary } \\
\text { because it was always the board that } \\
\text { initiated the implementation of MBV } \\
\text { concept } \\
\text { - The decision about values was a joint } \\
\text { decision of the managers and employees }\end{array}$ \\
\hline $\begin{array}{l}\text { 2. Communicating the mission and values } \\
\text { 2.1. Initial meetings in each location } \\
\text { 2.2. Acquiring at least basic knowledge of } \\
\text { the rules by employees } \\
\text { 2.3. Visual enhancement of values } \\
\text { 2.4. Developing a decision-making guidebook } \\
\text { 2.5. Communicating rules to other } \\
\text { stakeholders }\end{array}$ & $\begin{array}{l}\text { Generally in accordance with the litera- } \\
\text { ture guidelines } \\
\text { Differences: } \\
\text { • Mondi Polska has not yet developed } \\
\text { a decision-making guidebook }\end{array}$ \\
\hline $\begin{array}{l}\text { 3. Aligning daily practices with the mission } \\
\text { and values } \\
\text { 3.1. Providing feedback to management } \\
\text { whether the rules work } \\
\text { 3.2. Taking corrective actions } \\
\text { 3.3. Taking into account employees' ideas } \\
\text { and suggestions } \\
\text { 3.4. Values become the way of resolving } \\
\text { conflicts } \\
\text { 3.5. A collection of success stories as exam- } \\
\text { ples of how rules work } \\
\text { 3.6. Values are manifest in all areas of } \\
\text { activity, i.e.: } \\
\text { - Recruitment } \\
\text { - On-boarding } \\
\text { - Training } \\
\text { - Employee assessments } \\
\text { • Promotion } \\
\text { • Remunerations } \\
\text { - Motivation } \\
\text { - Customer relations } \\
\text { - Financial results }\end{array}$ & $\begin{array}{l}\text { Generally in accordance with the litera- } \\
\text { ture guidelines } \\
\text { Differences: } \\
\text { - Mondi Polska has not yet directly } \\
\text { linked the compliance with rules and } \\
\text { the remuneration level } \\
\text { - The financial results of Mondi Polska } \\
\text { are not assessed by the values } \\
\text { - The rules are a leitmotif of company } \\
\text { events }\end{array}$ \\
\hline $\begin{array}{l}\text { Periodic diagnosis of whether Management by } \\
\text { Values functions at the operational level }\end{array}$ & $\begin{array}{l}\text { In accordance with the literature } \\
\text { guidelines }\end{array}$ \\
\hline
\end{tabular}

Source: author's compilation. 
The main difference between the literature guidelines and Mondi Polska's practice results from the fact that MBV was not implemented there in the course of its operation but at the very beginning. Moreover, it was initiated by the Management Board and not, e.g., by the HR department. The information presented in Table 2 also shows that MBV is not directly related to economic values, such as employee remuneration or the company's profits.

Sobiecki (2015) admitted that he had not come across empirical research showing the effectiveness of MBV implementation. The current case study presents a measurement method for this effectiveness. It refers to a regular study aimed at determining the degree to which the company's MBV rules are understood and consistent with personal principles and assessing the degree of compliance with standards. The above-presented results confirm to a high degree both the functioning of the company's values in practice and their compliance with the personal values of employees. Periodic comparison of the results of this survey helps managers to assess, whether the company has adopted the right personnel policy.

The case study discussed in the article - due to the fact that Mondi Polska constitutes a part of an international group of enterprises - can also be referred to the theory of international human resources management, in particular to the so-called "intercultural" management, which attracts attention to the need to develop a different organizational culture, comparing to the environment of "one culture", and a different approach to managing people in a multicultural environment (Spillan, 1997). Bearing in mind various types of cultural relations between the headquarters of an international corporation and its foreign subsidiaries, addressed by Heenan and Perlmutter, it should be stated that the analyzed case refers to the polycentric type (Murdoch, 1999).

A polycentric model of organizational culture means cultural diversity across the entire enterprise group. The advantage of such a situation is greater flexibility of subsidiaries, allowing for a quick and effective response to changes taking place in the economic, legal and market environment of the country they are located in. Multiculturalism, however, hinders the strategic management of human resources in the entire international group of companies and the standardization of recruitment and selection systems, the assessment process or manager development programs, for instance. 
It reduces the possibility of promoting employees by transferring them from a subsidiary to a parent company.

Finally, the academic literature points to the fact that various generational groups with diverse needs coexist in contemporary enterprises. Management board members who implemented MBV in the analyzed company are representatives of Generation X. Generation X are people born between 1965 and 1979. They remember a different reality and know that the way to professional success involves not only excellent education and competence but also commitment. They are also active outside the office, they develop their interests, yet not at the expense of work. They understand that it is worth working overtime for the sake of the project. Their younger colleagues, Millennials, in turn, feel that "the world is their oyster". The new generation in the labor market does not want to be bored, it wants to change the world. They also like to have access to modern technologies and frequent feedback (Piwowar-Sulej, 2014). It may be challenging for employers to find ways how to attract and retain young employees. The case study not only shows how to motivate Generation $\mathrm{Y}$ to act according to the common values but also proves that MBV can integrate representatives of different generations.

\section{CONCLUSIONS}

Management by values is a relatively new and development-oriented concept. Numerous empirical studies have shown that value systems represent motivators that influence employee behavior, and thus contribute to the overall success of the organization.

To sum up, the functioning of rules in the company under study, it should be clearly stated that they stand as the main principle in the company's operations. They support recruitment decision-making, indicate training directions, function as the core of motivational activities and are present in all relations with stakeholders and, in particular, with clients. Owing to the consistent implementation and monitoring of the standards' functioning in the enterprise, the company has recorded continuous growth for more than eight years, provides its employees with lots of satisfaction at work and ensures stable profits for the company owners. The findings presented herein provide managerial implications. The activities undertaken 
in Mondi Polska (with their specific tools) can be used in other enterprises, which constitutes the application value of the article.

Although the present study delivers some insights into the way of implementing management by values, it is not without limitations. The findings are highly specific to the studied business itself. More research is needed to examine these findings in other organizations in different sectors.

Despite the guidelines presented in the subject literature on how to implement MBV, this concept still results in many challenges for both practice and science. It would be interesting to continue the research in areas related to values such as the concept of OHS (occupational health and safety) culture (Piwowar-Sulej, 2019). An area in which HR specialists can make a contribution to support human capital for the sustainability of the companies is health and safety. Management boards of industrial enterprises - due to numerous accidents at work - emphasize the value of human health and life in particular. The question arises, at which position (if et all) the safety issues would be listed among the values selected by the employees themselves. According to different statistics, accidents at work happen due to improper employee behavior.

\section{REFERENCES}

Ambroziak, D. (2012). Jak diagnozować zarzadzanie przez wartości w organizacji? Dwa poziomy diagnozy prowadzace do jednego celu. Warszawa: Instytut Gaussa Sp. z o.o.

Bell-Laroche, D., MacLean, J., Thibault, L. \& Wolfe, R.A. (2014). Leader perceptions of management by values within Canadian national sport organizations. Journal of Sport Management, 28, 68-80, doi:10.1123/jsm.2012-0304.

Blanchard, K.H. \& O’Connor, M.J. (1997). Managing by values: How to Put Your Values Into Action for Extraordinary Results. San Francisco: Berrett-Koehler Publishers.

Bozeman, B. (2007). Public values and public interest: Counterbalancing economic individualism. Washington: Georgetown University Press.

Cameron, K.S. \& Quinn, R.E. (2003). Kultura organizacyjna-diagnoza i zmiana: model wartości konkurujacych. Warszawa: Wolters Kluwer.

Chandrakumara, P. (2011). Value of Values for Practicing Managers and Leaders. Problems and Perspectives in Management, 9(2), 80-88. 
Chelladurai, P. \& Kerwin, S. (2017). Human Resource Management in Sport and Recreation. Champaign: Human Kinetics.

Cho, Y.J. \& Perry, J.L. (2012). Intrinsic Motivation and Employee Attitudes: Role of Managerial Trustworthiness, Goal Directedness, and Extrinsic Reward Expectancy. Review of Public Personnel Administration, 32, 382-406, doi:10.1177/0734371X11421495.

Collins, J. \& Porras, J.I. (2004). Built to Last: Successful Habits of Visionary Companies. New York: Harper Business.

Delshab, V., Winand, M., Boroujerdi, S.S., Pyun, D.Y. \& Mahmoudian, A. (2019). Analyzing the influence of employee values on knowledge management in sport organizations. Journal of Science and Technology Policy Management, 10(3), 667-685, https://doi.org/10.1108/ JSTPM-04-2018-0039.

Denier, Y., Dhaene, L. \& Gastmans, C. (2019). 'You can give them wings to fly': a qualitative study on values-based leadership in health care. BMC Medical Ethics, 20, 35, doi:10.1186/s12910-019-0374-x.

Dolan, L. \& Salvador, G.S. (2000). Managing by Values in the Next Milenium: Cultural Redesign for Strategic Organizational Change, https://papers.ssrn. com/sol3/papers.cfm?abstract_id=237628, doi.org/10.2139/ssrn.237628.

Dolan, S.L. \& García, S. (2001). Managing by values - Cultural redesign for strategic organizational change at the dawn of the twenty-first century. Journal of Management Development, Vol. 21, No. 2, 2002, 101-117, doi:10.1108/02621710210417411.

Dolan, S.L., García, S. \& Auerbach, A. (2003). Understanding and managing chaos in organisations. International Journal of Management, 20, 23-35.

Dolan, S.L., Garcia, S. \& Richley, B. (2006). Managing by Values. A Corporate Guide to Living, Being Alive, and Making a Living in the 21st Century. London: Palgrave Macmillan.

Encyclopedia of Management $\quad$ (n.d.). https://mfiles.pl/pl/ (Accessed: $7^{\text {th }}$ April 2019).

Goll, G. (1990). Management by Values: consistency as a predictor of success. Hospitality Research Journal, 14(1), 55-68, doi:10.1177/109634809001400106.

Górniak, L. (2015). Zarządzanie przez wartości jako metoda angażowania pracowników. Zeszyty Naukowe Uniwersytetu Ekonomicznego w Krakowie, 8, 101-116, doi:10.15678/ZNUEK.2015.0944.0809.

Górniak, L (2016). Preferowane wartości organizacyjne a zaangażowanie pracowników. E-Mentor, 5, 21-26.

Hancock, J. (n.d.). The Value of Values: A Guide for Managers, https://www.worldvaluesday.com/tools-and-resources/managers-guide-values/ (Accessed: $18^{\text {th }}$ September 2019). 
Harung, H.S \& Dahl, T. (1995). Increased productivity and quality through management by values: A case study of Manpower Scandinavia. The TQM Magazine, 7(2), April 1995, 13-22, doi: 10.1108/09544789510081063.

Herman, A. \& Konopka, D. (2013). Zarządzanie przez wartości drogą do zrównoważonego i społecznie odpowiedzialnego rozwoju. Zeszyty Naukowe Uniwersytetu Szczecińskiego, 786, 33-40.

Hockerts, K. (1999). The Sustainability Radar: A Tool for the Innovation of Sustainable Products and Services. Greener Management International, $25,29-49$.

Ibarreche, S. (2016), Simon Dolan: managing by values - if you are not spiritual, how can you inspire? Management Research: The Journal of the Iberoamerican Academy of Management, Vol. 14, No. 2, 2016, 188-207, doi: 10.1108/MRJIAM-06-2016-0674.

Jaakson, K. (2009). Management by values: the analysis of influencing aspects and its theoretical and practical implications. Estonia: University of Tartu.

Jaakson, K. (2010). Management by values: Are some values better than others? Journal of Management Development, 29, 795-806, doi:10.1108/02621711011072504.

Kerwin, S., MacLean, J. \& Bell-Laroche, D. (2014). The mediating influence of management by values in nonprofit sport organizations. Journal of Sport Management, 28, 646-656, doi:10.1123/JSM.2013-0303.

Lachowski, S. (2012). Droga ważniejsza niż cel. Wartości w życiu i biznesie. Warszawa: Studio Emka.

Lachowski, S. (2012a). Zarządzanie przez wartości odpowiedzią na wyzwania przyszłości. Kwartalnik Nauk o Przedsiębiorstwie, 1, 13-24.

Lipińska, J. (2010). Zarządzanie przez wartości. In: R. Knosala (ed.). Komputerowo zintegrowane zarzadzanie, 122-130. Opole: Oficyna Wydawnicza Polskiego Towarzystwa Zarządzania Produkcją.

Mandalaki, E, Islam, G. \& Sobral, F. (2017). Leading organizational change in a Brazilian multinational. In: D. Halkias, J.C. Santora, N. Harkiolakis \& P.W. Thurman (eds.). Leadership and Change Management, 7-17. New York: Routledge.

Marek, A. (2018). Adjusting the employee management process to key organisational values. Central European Review of Economics and Management, 2(4), 111-126, https://doi.org/10.29015/cerem.421.

Mikkelsen, M.F., Jacobsen, Ch.B. \& Andersen, L.B. (2017). Managing Employee Motivation: Exploring the Connections Between Managers' Enforcement Actions, Employee Perceptions, and Employee Intrinsic Motivation. International Public Management Journal, 20(2), 183-205, doi:10.1080/10967 494.2015.1043166. 
Murdoch, A. (1999). Wspótpraca z cudzoziemcami w firmie. Warszawa: Poltext.

Paarlberg, L.E. \& Perry, J.L. (2007). Values Management. The American Review of Public Administration, 37(4), 387-408, doi:10.1177/0275074006297238.

Peters, T.J. \& Waterman, R. (2002). Poszukiwanie doskonałości w biznesie, trans. E. Abłamowicz, H. Kobylińska. Warszawa: Medium.

Pietsch, G. (2006). Wertorientierte Personalarbeit zwischen Mythos und Mikropolitik. Zeitschrift für Personal Forschung/ German Journal of Research in Human Resource Management, 20, 160-182.

Piwowar-Sulej, K. (2014). Factors in motivating generation y employees - polish realities. Economy \& Business, 8, 1124-1131.

Piwowar-Sulej, K. (2019). Kultura bezpieczeństwa w przemyśle chemicznym w Polsce. Przemyst Chemiczny, 98, 1646-1652, doi:10.15199/62.2019.10.24.

Sagan, A. (2011). Wartość dla klienta $w$ układach rynkowych : aspekty metodologiczne. Kraków: Wydawnictwo Uniwersytetu Ekonomicznego w Krakowie.

Sobiecki, G. (2015). Koncepcja zarządzania przez wartości. Studia i Prace Kolegium Zarzqdzania i Finansów SGH, 145, 9-31.

Spillan, J.E. (1997). Zarządzanie na styku kultur. In: M.K. Nowakowski (ed.). Bariery internacjonalizacji przedsiębiorstwa, 49-55. Warszawa: Key Text.

Stachowicz-Stanusch, A. (2017). Potęga wartości. Jak zbudować nieśmiertelna firme. Gliwice: Helion.

Stake, R.E. (2005). Case Studies. In: N. Denzin \& Y. Lincoln (eds.). Handbook of Qualitative Research, 445-456. London-New Delhi: SAGE Publications Inc.

Swaroopa, Br.P. \& Chandrasekhar, T.D. (2019). Good Values, Great Business. New Delhi: Sage Publications.

Świątek-Barylska, I. (2010). Zarządzanie przez wartości jako podstawa trwania i rozwoju organizacji - teoria i praktyka. Zeszyty Naukowe Uniwersytetu Szczecińskiego, 598, 571-578.

Świątek-Barylska, I. (2017), Core Values and Formalization as Determinants of Individual Behavior in an Organization. In: Z. Nedelko \& M. Brzozowski (eds.). Exploring the Influence of Personal Values and Cultures in the Workplace, 25-38. Hershey: IGI Global.

Titov, E. \& Umarova, L. (2017). Impact of Real and Propagated Values on Organizational Success. In: J. Vveinhardt (ed.). Congruence of personal and organizational values, 13-29. Rijeka: InTech.

Value Descriptors (n.d.). http://www.minessence.net/PDFs/ValueDescriptorList.pdf (Accessed: $8^{\text {th }}$ October 2019).

Walsham, G. (1995). Interpretative case studies in IS research. Nature and method. European Journal of Information Systems, 4, 74-81, doi:10.1057/ ejis.1995.9. 
Yin, R.K. (2013). Case study research: Design and methods. Thousand Oaks: SAGE Publications Inc.

Zavyalova, E. (2009). Management by Values As a Core Tool of HRD During the Economic Transition: An Example of Russian Enterprises. Human Resource Development International, 12:4, 449-457, doi:10.1080/13678860903135870.

Zhang, Y., Dolan, S. \& Zhou, Y. (2009). Management by Values: A Theoretical Proposal for Strategic Human Resource Management in China. Chinese Management Studies, Vol. 3, No. 4, 2009, 272-294, doi:10.1108/17506140911007468. 


\section{ZARZĄDZANIE PRZEZ WARTOŚCI - STUDIUM PRZYPADKU PRZEDSIĘBIORSTWA Z BRANŻY REKRUTACYJNEJ}

\section{Abstrakt}

Tło. Chociaż w literaturze przedmiotu można znaleźć informacje na temat wdrażania zarządzania przez wartości (ZPW), koncepcja ta jest wciąż stosunkowo nowa i pozostawia pole do rozwoju. Na przestrzeni lat udowodniono, że istnieje bezpośredni związek pomiędzy zarządzaniem przez wartości a wynikami ekonomicznymi organizacji.

Cele badawcze. Celem pracy jest udzielenie odpowiedzi na następujące pytania badawcze: „Jakie są źródła i założenia koncepcji zarządzania przez wartości?” oraz „Jak organizacja powinna wdrażać i utrzymywać ZPW?”.

Metodologia. Autorzy wykorzystali opracowania literatury rodzimej oraz zagranicznej w tym obszarze, a także metodę longitudialnego studium przypadku. W ramach studium przypadku autorzy zastosowali obserwacje uczestników (przeprowadzone w ciagu 8 lat), analizę dokumentacji i inne informacje o badanym przedsiębiorstwie, takie jak raporty wewnętrzne czy strona internetowa. Przeprowadzili również wywiady z 3 członkami zarządu i 8 pracownikami. Wyniki badań empirycznych skonfrontowali z przedstawioną w literaturze koncepcja „mapy drogowej”.

Kluczowe wnioski. Badania ujawniły pewne różnice między praktyką a „mapa drogowa”. W artykule przedstawiono wskazówki dla menedżerów, np. jak zoperacjonalizować wartości firmy, jak budować system motywacyjny, jak mierzyć sukces wdrożenia ZPW. W artykule przedstawiono również proponowane kierunki dalszych badań.

Słowa kluczowe: wartości, zarządzanie przez wartości, wdrożenie, longitudialne studium przypadku. 